\title{
Efektywność w zmienności? 0 roli instytucji pomocy społecznej w dobie nowych ryzyk socjalnych
}

\section{Wstęp}

Instytucja opieki i pomocy społecznej nigdy nie znajdowała się w centrum zainteresowania władz państwowych. „Na pomocy społecznej ciąży piętno "gorszego « systemu świadczeniowego - pisał H. Szurgacz - przeznaczonego zresztą jakoby dla ludzi innego, również "gorszego « rodzaju”2. Sugestia to w pełni zrozumiała, gdy weźmie się pod uwagę fakt, iż od samego początku funkcjonowania pomocy społecznej w Polsce (nazywanej wtedy opieką społeczną) - tj. od czasów Drugiej Rzeczypospolitej - pojawiały się głosy o rychłym zaniku tej instytucji publicznej czy też o przejęciu jej roli przez dynamicznie rozwijające się wtedy ubezpieczenia społeczne ${ }^{3}$. Jeszcze gorzej z tą instytucją obeszły się władze Polskiej Rzeczpospolitej Ludowej, traktując - w początkowej fazie rozwoju systemu realnego socjalizmu opiekę społeczną jako „niewarty wspominania relikt kapitalistycznej Polski” 4 . I choć obecnie lansowany do lat 60 . XX w. pogląd o zaniku pomocy społecznej traktowany jest jako niechlubny epizod w historii tej instytucji, to wciąż pojawiają się głosy o szkodliwości systemu pomocy społecznej tym razem w kontekście jego społecznych skutków ${ }^{5}$.

W niniejszym tekście - w pewnym stopniu na przekór powyższym słowom - chciałbym przyjrzeć się ogromnemu w moim odczuciu potencjałowi tkwiącemu w instytucji pomocy społecznej, a szczególnie jej funkcji

1 Dr Krzysztof Chaczko, Uniwersytet Pedagogiczny im. Komisji Edukacji Narodowej w Krakowie, ul. Podchorążych 2, 30-084 Kraków.

2 H. Szurgacz, Wstęp do prawa pomocy społecznej, Wrocław 1992, s. 6.

3 Zob. na ten temat ibidem, s. 7 i n. oraz K. Krzeczkowski, Uwagi nad drogami opieki społecznej, Warszawa 1936.

4 K. Chaczko, „Polska w soczewce”. Ewolucja oraz modernizacja systemu opieki i pomocy społecznej w perspektywie instytucjonalnej, „Rocznik Administracji Publicznej” 2016, nr 2, s. 359.

5 Zob. np. S. Kalinowski, Niewolnicy pomocy - świadczenia społeczne jako czynnik dezaktywujący [w:] Nieobecność społeczna. W poszukiwaniu sensów i znaczeń, Z. Galor, B. Goryńska-Bittner (red.), Poznań 2012, s. 204-224. 
innowacyjnej. Tematyka to wciąż mało znana, choć ostatnio coraz częściej poruszana w tekstach naukowych ${ }^{6}$, a wydaje się, iż warta uwagi szczególnie dziś, gdyż - stawiam tu roboczą hipotezę - poza instytucją pomocy społecznej żadna $\mathrm{z}$ form zabezpieczenia społecznego nie będzie raczej $\mathrm{w}$ stanie poradzić sobie z narastającymi problemami społecznymi będącymi efektem globalizacji czy gospodarki neoliberalnej ${ }^{7}$. Mam tu na myśli głównie tzw. nowe ryzyka socjalne, które - jeśli już nie pojawiły się w Polsce - to wydają się być nieuchronne.

\section{Od ryzyk indywidualnych do starych ryzyk socjalnych}

Rozwój (nowoczesnej) polityki społecznej można rozumieć jako proces publicznego zarządzania ryzykami socjalnymi ${ }^{8}$. Przyjmując taką optykę a ku temu się skłaniam - wysuwamy kategorię ryzyka socjalnego na pierwszy plan. Słownikowa definicja wspomnianego terminu informuje o zdarzeniach losowych lub innych, których „wystąpienie wywołuje podjęcie odpowiednich działań $w$ ramach zabezpieczenia społecznego. Chodzi tu przede wszystkim o te zdarzenia, które powodują utratę lub zmniejszenie możliwości zdobywania środków utrzymania własną pracą czy też skutkują niedostosowaniem wysokości dochodów do potrzeb rodzin"9. Mowa tu o konkretnych sytuacjach występujących w trakcie cyklu życia człowieka, które Międzynarodowa Organizacja Pracy już w 1944 r. ujęła w klasyczny katalog podstawowych ryzyk socjalnych:

- ryzyko na wypadek choroby (ang. sickness),

- ryzyko macierzyństwa (ang. maternity),

- ryzyko niezdolności do pracy (ang. invalidity),

6 Zdaje się, iż jedną z pierwszych osób, która - ponad dwie dekady temu - poświęciła temu zagadnieniu nieco miejsca, był H. Szurgacz w pracy Wstęp do prawa pomocy społecznej..., s. 16-20. Obecnie częściej tematykę innowacyjności podejmuje się w szerszym kontekście, tj. polityki społecznej. Zob. np. Innowacyjna polityka społeczna, M. Grewiński, A. Karwacki (red.), Warszawa 2015, a szczególnie rozdział J. Krzyszkowskiego Kreowanie i wdrażanie innowacji w pomocy społecznej, s. 191-203.

7 Zob. U. Beck, Społeczeństwo ryzyka. W drodze do innej nowoczesności, Warszawa 2002.

8 G. Esping-Andersen, Społeczne podstawy gospodarki postindustrialnej, Warszawa 2010, s. 52. Warto zauważyć, iż w literaturze przedmiotu obok terminu ryzyka socjalnego funkcjonuje także kategoria ryzyka społecznego. T. Szumlicz sugeruje, iż dookreślenie „socjalne” wyraża poziom przedmiotowy i „techniczny” tego zwrotu, zaś dookreślenie „społeczne” zwraca uwagę na poziom podmiotowy terminu oraz jego wymiar i zasięg społeczny (T. Szumlicz, Publiczne fundusze socjalne - istota oraz organizacja i funkcjonowanie w Polsce, „Studia z Polityki Publicznej” 2014, nr 1, s. 83, przyp. 5). Mając to na uwadze, skłaniam się jednak ku używania (tradycyjnego) zwrotu „ryzyka socjalne”, uwypuklającego - jak chce T. Szumlicz - aspekt przedmiotowy, czyli kwestię zmniejszenia lub zaniku dochodów w przypadku wystąpienia tych ryzyk.

9 Leksykon polityki społecznej, B. Rysz-Kowalczyk (red.), Warszawa 2001, s. 189. 
- ryzyko dożycia wieku starczego (ang. old age),

- ryzyko śmierci żywiciela (ang. death of breadwinner),

- ryzyko braku pracy (ang. unemployment),

- ryzyko nieoczekiwanych wydatków (ang. emergency expenses),

- ryzyko wypadku przy pracy (ang. employment injuries) ${ }^{10}$.

$\mathrm{W}$ następnych latach nieznacznie poszerzono powyższe zestawienie o ryzyko ubóstwa (ang. poverty) oraz ryzyko niedołęstwa starczego (ang. old-age infirmity) ${ }^{11}$.

Generalnie do XX w. większość wspomnianych ryzyk nie miało wymiaru społecznego co oznacza, iż nie były przedmiotem zainteresowania państwa. Pamiętajmy wszak, iż dziewiętnastowieczne społeczeństwa wciąż były $\mathrm{w}$ przeważającej mierze wiejskie, gdzie wielopokoleniowa rodzina spełniała $\mathrm{w}$ pewnym sensie obecne funkcje socjalne państwa, a ponadto infrastruktura administracji publicznej tamtych czasów oraz struktura budżetów ówczesnych państw uniemożliwiały realizację „kolektywizacji ryzyka socjalnego na masową skalę"12.

Zbiorowy charakter ryzyka socjalne zyskały w okresie industrializacji gospodarek (europejskich), kiedy to ryzyka indywidualne stopniowo podlegały procesowi „uspołecznienia” czy też „upolitycznienia”"13. Stało się to pod wpływem przynajmniej trzech czynników.

Po pierwsze, nastąpiła „kumulacja” losów wielu jednostek, początkowo robotników fabrycznych, a następnie innych grup społecznych, co oznaczało, iż pod względem ilościowym ubóstwo tych jednostek miało skutek zbiorowy, powodując zagrożenie utrzymania ładu społecznego. „Uspołecznianie" ryzyk socjalnych rozpoczęło się od niwelacji zagrożeń związanych $\mathrm{z}$ wykonywaniem prac w fabrykach (choroba oraz wypadki przy pracy), by

10 Income Security Recommendation, 1944 (No. 67) na stronie Międzynarodowej Organizacji Pracy: http://www.ilo.org/dyn/normlex/en/f?p=NORMLEXPUB:12100:0::NO::P12100_INSTRUMENT_ID:312405 (dostęp: 30.10.2016). Por. też Konwencję nr 102 Międzynarodowej Organizacji Pracy dotyczącą minimalnych norm zabezpieczenia społecznego, przyjętą w Genewie dnia 28 czerwca 1952 r., Dz. U. z 2005 r. Nr 93, poz. 775. Współczesne badania nad kategorią ryzyka socjalnego przedstawia G. Uścińska, Ryzyko jako przesłanka ochrony w systemie zabezpieczenia społecznego, „Polityka Społeczna" 2013, nr 11-12, s. 3-7.

11 T. Szumlicz, Publiczne fundusze socjalne - istota oraz organizacja i funkcjonowanie $w$ Polsce..., s. 84.

12 G. Esping-Andersen, Społeczne podstawy gospodarki postindustrialnej..., s. 48.

13 B. Ponikowski proces ten nazwał „uspołecznieniem pracy”. Stwierdził, iż doniosłym odkryciem czasów nowożytnych stało się pojmowanie człowieka jako istoty społecznej. „Wynikało ono z przekształcenia się pracy jako naturalnej i najbardziej prywatnej czynności ludzkiej w pracę społeczną. W ten sposób to, co dotychczas należało do sfery prywatnej, stało się czymś publicznym", B. Ponikowski, Problem państwa socjalnego w perspektywie globalizacji [w:] Uwarunkowania współczesnej polityki społecznej, B. Ponikowski, J. Zarzeczny (red.), Wrocław 2002, s. 22. 
systematycznie obejmować pozostałe zdarzenia związane z zanikiem dochodów pracownika ${ }^{14}$.

Po drugie, społeczeństwa - a za nimi organy decyzyjne - uznały, iż określone ryzyka (np. macierzyństwo) wymagają po prostu publicznej uwagi ze względu na ich doniosłość społeczną. Idąc tym tropem, możemy stwierdzić, iż katalog ryzyk socjalnych nie jest zamknięty i prawdopodobnie będzie powiększał się wraz z rozwojem cywilizacyjnym (i związanymi z tym problemami).

Po trzecie, okazało się, iż często źródła ryzyk socjalnych leżą poza kontrolą jednostki. Fizyczna niezdolność do pracy, starość czy choroba to zdarzenia, na które jednostka czy rodziny mają niewielki wpływ, dlatego zdjęcie ciężaru tych ryzyk $\mathrm{z}$ wymienionych podmiotów i przeniesienie ich na instytucję państwa wydawało się jedynym możliwym rozwiązaniem w epoce uzależnienia od dochodu rynkowego ${ }^{15}$.

\section{Formy minimalizacji skutków starych ryzyk socjalnych}

Proces „uspołeczniania” wspomnianych ryzyk socjalnych spowodował wypracowanie form zapewniania źródeł dochodów obywatelom przez instytucje publiczne w momencie wytępienia zasygnalizowanych wyżej sytuacji, co legło u podstaw koncepcji państwa bezpieczeństwa socjalnego (ang. welfare state ${ }^{16}$. Współcześnie zbiór tych form określa się mianem systemu zabezpieczenia społecznego, definiowanego przez J. Piotrowskiego jako „całokształt środków i działania instytucji publicznych, za pomocą których społeczeństwo stara się zabezpieczyć swych obywateli przed niezawinionym przez nich niedostatkiem, przed groźbą niemożności zaspokojenia podstawowych, społecznie uznanych za ważne, potrzeb"17. Wspomniane środki zapewniane przez instytucje publiczne to świadczenia (głównie pieniężne), które przyjmują - w zależności od formy (lub techniki) zabezpieczeniowej - charakter ubezpieczeniowy, zaopatrzeniowy lub opiekuńczy (zwany także pomocowym) $)^{18}$.

14 Zob. B. Palier, Ordering change: understanding the „Bismarckian” welfare reformy trajectory [w:] A long goodbye to Bismarck? The politics of welfare reform in Continental Europe, B. Palier (ed.), Amsterdam 2010, s. 19-44; M. Księżopolski, Polityka społeczna. Wybrane problemy porównań międzynarodowych, Katowice 1999, s. 26-52; A. Żarnowska, Robotnicy Warszawy na przełomie XIX i XX wieku, Warszawa 1985, s. 134-158.

15 Zob. G. Esping-Andersen, Społeczne podstawy gospodarki postindustrialnej..., s. 53.

16 Por. B. Jagusiak, Bezpieczeństwo socjalne wspótczesnego państwa, Warszawa 2015.

17 J. Piotrowski, Zabezpieczenie społeczne - problematyka i metody, Warszawa 1966, s. 28.

$18 \mathrm{~W}$ ostatnich latach sugeruje się, iż ze względu na proces pojawiania się nowych elementów w systemie zabezpieczenia społecznego powinno się mówić o funkcjonowaniu kolejnej (nowej) części systemu. Zwraca na to uwagę I. Sierpowska, pisząc, iż „rozrastający się obszar prawnych regulacji powoduje powstawanie świadczeń hy- 
Najpowszechniejszą techniką zabezpieczenia społecznego jest technika ubezpieczeniowa. Świadczenia udzielane w ramach tej formy ubezpieczeń społecznych mają charakter roszczeniowy i opierają się na systemie składkowym, co oznacza, iż do nabycia uprawnień wymagane jest opłacanie składek zasilających określony fundusz, z którego w sytuacji zaistnienia zdarzenia losowego (ryzyka) uniemożliwiającego świadczenie pracy wypłacane są świadczenia pieniężne ${ }^{19}$. W przypadku metody zaopatrzeniowej również mamy do czynienia $\mathrm{z}$ charakterem roszczeniowym świadczeń, jednak inny jest sposób ich finansowania i nabywania. Świadczenia zaopatrzeniowe finansowane są funduszy publicznych (nieskładkowych), zaś wysokość, zasady i warunki tych świadczeń określają różne przepisy prawa. $Z$ reguły przysługują one obywatelom należącym do określonej grupy społecznej bądź zawodowej, np. osobom niepełnosprawnym od urodzenia ${ }^{20}$. Najmniej powszechną i pełniącą poniekąd funkcję uzupełniającą do wskazanych wyżej form zabezpieczenia społecznego jest technika opiekuńcza, realizowana przez instytucję pomocy społecznej. Jako że instytucja ta stanowi główny wątek niniejszego artykułu, warto przyjrzeć się jej bliżej.

Pomoc społeczna jest jedną z najstarszych form udzielania świadczeń jednostkom potrzebującym wsparcia, czyli osobom, które nie dysponują dochodami zapewniającymi zaspokojenie fundamentalnych potrzeb ${ }^{21}$. Jak twierdzi P. Błędowski, „Pomoc nie jest jednak ograniczona wyłącznie do interwencji w przypadku, gdy zawodzą inne podsystemy zabezpieczenia społecznego. Uwzględnienie w kategorii trudnych sytuacji życiowych elementów pozamaterialnych sprawia, że świadczenia pomocy mają coraz częściej charakter samodzielny wobec ubezpieczenia społecznego"22. Usta-

brydowych, opartych na mieszanych metodach. Rodzi to trudności ich klasyfikacji, zwłaszcza oddzielenia świadczeń o charakterze zaopatrzeniowym i pomocowym. Dodatkową trudnością jest zaliczanie do zaopatrzenia społecznego świadczeń przyznawanych ze względu na potrzeby i zasługi, które znacznie się od siebie różnią. Dlatego we współczesnej literaturze proponuje się wyodrębnienie wsparcia społecznego (socjalnego), jako jeszcze jednej części systemu zabezpieczenia społecznego, umieszczonego pomiędzy zaopatrzeniem a pomocą społeczną", I. Sierpowska, Istota i zasady udzielania pomocy społecznej [w:] Meritum. Pomoc społeczna. Wsparcie socjalne, I. Sierpowska (red.), Warszawa 2016, s. 3.

19 M. Księżopolski, G. Magnuszewska-Otulak, R. Gierszewska, Zabezpieczenie społeczne [w:] Polityka społeczna, A. Rajkiewicz, J. Supińska, M. Księżopolski (red.), Warszawa 1996, s. 249.

20 M. Orłowska-Bednarz, M. Bednarz, Zabezpieczenie społeczne jako forma ochrony warunków życia, „Miscellanea. Studia z Zakresu Nauk Prawnoustrojowych” 2012, nr 2, s. 61-62.

21 Przez setki lat opieka/pomoc społeczna utożsamiana była z działalnością filantropijną i dobroczynną. Zob. E. Leś, Zarys historii dobroczynności i filantropii w Polsce, Warszawa 2001; J. Radwan-Pragłowski, K. Frysztacki, Społeczne dzieje pomocy człowiekowi: od filantropii greckiej do pracy socjalnej, Warszawa 1996.

22 P. Błędowski, Pomoc społeczna [w:] Polityka społeczna, A. Kurzynowski (red.), Warszawa 2006, s. 233. 
wa o pomocy społecznej z 2004 r. wyraźnie określa przesłanki udzielania pomocy przez tę instytucje, tj. ubóstwa, sieroctwa, bezdomności, bezrobocia, niepełnosprawności, długotrwałej lub ciężkiej choroby, przemocy $\mathrm{w}$ rodzinie, potrzeby ochrony macierzyństwa lub wielodzietności, bezradności w sprawach opiekuńczo-wychowawczych, trudności w integracji cudzoziemców, trudności w przystosowaniu do życia po zwolnieniu z zakładu karnego, alkoholizmu lub narkomanii, zdarzenia losowego i sytuacji kryzysowej oraz klęski żywiołowej lub ekologicznej ${ }^{23}$. Jak nietrudno zauważyć, powody przyznania wsparcia z instytucji pomocy społecznej znacznie wykraczają poza wskazany wyżej katalog ryzyk socjalnych, ale pamiętajmy, iż dostęp do większości świadczeń pieniężnych obwarowany jest kryterium dochodowym ${ }^{24}$, czyli poziomem osiąganych dochodów, czy to w przypadku osoby samotnie gospodarującej, czy osoby w rodzinie ${ }^{25}$. Z tego też powodu sytuacja ekonomiczna klientów pomocy społecznej jest podstawowym kryterium udzielania świadczeń przez pracowników socjalnych i dlatego zazwyczaj pomoc finansowa należy się osobom pozbawionym uprawnień przysługujących z systemu ubezpieczeń społecznych.

Niezwykle istotnym w świetle podejmowanych rozważań, aczkolwiek wciąż niedocenianym i niewątpliwie zmarginalizowanym obszarem funkcjonowania pomocy społecznej, jest sfera usług społecznych ${ }^{26}$. Pomoc społeczna w Polsce - szczególnie po transformacji ustrojowej - była nastawiona głównie na redystrybucję świadczeń pieniężnych i rzeczowych. Z kolei usługi społeczne, np. aktywizacja i reintegracja społeczna, praca socjalna czy usługi w obszarze ekonomii społecznej, traktowano marginalnie, a jeśli już się pojawiały, to głównie w działalności organizacji pozarządowych i niektórych nowatorskich podmiotów z zakresu publicznej pomocy społecznej ${ }^{27}$. Tym samym marnowała się, i jak się wydaje - wciąż marnuje się, ogromna wartość usług społecznych, którą doskonale obrazuje tab. 1. Zestawienie świadczeń pieniężnych oraz wspomnianych usług wyraźnie uwidacznia pasywny charakter tych pierwszych oraz prorozwojową, aktywizującą naturę usług społecznych, które - o czym będzie mowa niżej - cechują się indywidualnością oraz „elastycznością”.

23 Ustawa z dnia 12 marca 2004 r. o pomocy społecznej, tekst jedn.: Dz. U. z 2016 r. poz. 930 ze zm.

24 Do wyjątków należy specjalny zasiłek celowy oraz zasiłek celowy przyznawany w sytuacji klęski żywiołowej lub ekologicznej.

25 Od 1 października 2015 r. kryterium dochodowe dla osoby samotnie gospodarującej wynosi 634 zł, zaś dla osoby w rodzinie 514 zł. Zob. rozporządzenie Rady Ministrów z dnia 14 lipca 2015 r. w sprawie zweryfikowanych kryteriów dochodowych oraz kwot świadczeń pieniężnych z pomocy społecznej, Dz. U. poz. 1058.

26 Zob. K. Chaczko, Ile jest pomocy w pomocy społecznej? Rzecz o marginalizacji działań usamodzielniających, „Teraźniejszość - Człowiek - Edukacja. Kwartalnik myśli społeczno-pedagogicznej” 2017, nr 1 (77), t. 20, s. 111-121.

27 M. Grewiński, J. Lizut, Pomoc społeczna jako realizator efektywnych usług socjalnych, Toruń 2012, s. 32. 
Tabela 1. Świadczenia pieniężne a usługi społeczne

\begin{tabular}{|l|l|l|}
\hline \multicolumn{1}{|c|}{ Obszary } & \multicolumn{1}{|c|}{ Świadczenia pieniężne } & \multicolumn{1}{c|}{ Usługi społeczne } \\
\hline Niepełnosprawność & $\begin{array}{l}\text { Renta z tytułu niezdolności do } \\
\text { pracy, renty socjalne }\end{array}$ & $\begin{array}{l}\text { Rehabilitacja lecznicza, } \\
\text { zawodowa, społeczna, } \\
\text { pedagogiczna, psychologiczna, } \\
\text { opieka, pielęgnacja }\end{array}$ \\
\hline Starość & $\begin{array}{l}\text { Emerytury, zasiłki } \\
\text { pielęgnacyjne }\end{array}$ & $\begin{array}{l}\text { Pomoc w codziennym } \\
\text { funkcjonowaniu, opieka, } \\
\text { pielęgnacja }\end{array}$ \\
\hline $\begin{array}{l}\text { Śmierć członka } \\
\text { rodziny }\end{array}$ & $\begin{array}{l}\text { Renta rodzinna, zasiłek } \\
\text { pogrzebowy }\end{array}$ & $\begin{array}{l}\text { Sprawienie pogrzebu, pomoc } \\
\text { psychologiczna }\end{array}$ \\
\hline Rodzina, dzieci & $\begin{array}{l}\text { Zasiłki rodzinne, stypendia } \\
\text { w systemie oświaty }\end{array}$ & $\begin{array}{l}\text { Edukacja, poradnictwo } \\
\text { rodzinne, rodzicielstwo } \\
\text { zastępcze, opieka, pielęgnacja }\end{array}$ \\
\hline Bezrobocie & Zasiłki dla bezrobotnych & $\begin{array}{l}\text { Pośrednictwo pracy, } \\
\text { poradnictwo zawodowe, } \\
\text { edukacja, szkolenia }\end{array}$ \\
\hline $\begin{array}{l}\text { Wykluczenie } \\
\text { społeczne } \\
\text { i pozostałe }\end{array}$ & $\begin{array}{l}\text { Zasiłek okresowy, zasiłek } \\
\text { stały, pieniężna pomoc } \\
\text { postpenitencjarna }\end{array}$ & $\begin{array}{l}\text { Praca socjalna, resocjalizacja } \\
\text { społeczna }\end{array}$ \\
\hline
\end{tabular}

Źródło: M. Grewiński, J. Lizut, Pomoc społeczna..., s. 69.

\section{Nowe ryzyka socjalne a rola pomocy społecznej}

Pojawienie się tzw. nowych ryzyk socjalnych niewątpliwie wiąże się ze zmianami następującymi w społeczeństwach postprzemysłowych ${ }^{28} \mathrm{Z}$. Czepulis-Rutkowska twierdzi, iż „koncepcja nowych ryzyk socjalnych służy (...) wskazaniu trudnych sytuacji - głównie, ale nie tylko - materialnych, które pojawiły się w efekcie zmian postindustrialnych. Jest przeciwstawna koncepcji starych ryzyk socjalnych. Tak zwane stare ryzyka socjalne wiązane są z wcześniejszym, industrialnym okresem rozwoju ekonomiczno-społecznego. Były one dobrze zdiagnozowane w polityce społecznej, podobnie jak instytucje, które zapewniały ochronę w przypadku realizacji takich ryzyk" ${ }^{29}$. Najczęściej wśród nowych ryzyk socjalnych wymienia się następujące zagrożenia:

- ryzyko niedostatku wśród osób pracujących (niskie zarobki),

- ryzyko niskich świadczeń, np. w wieku emerytalnym,

- ryzyko niesamodzielności,

- ryzyko brak kwalifikacji do podjęcia odpowiedniej pracy,

- ryzyko młodego wieku ${ }^{30}$.

28 Zob. P. Sztompka, Socjologia. Analiza społeczeństwa, Kraków 2012, s. 567-570.

29 Z. Czepulis-Rutkowska, Nowe ryzyka socjalne, „Polityka Społeczna” 2013, nr $11-12$, s. 9.

30 Ibidem, s. 9-14. W kontekście ryzyka młodego wieku P.W. Zawadzki twierdzi, iż „Mamy do czynienia z osobami młodymi, dobrze wykształconymi, z którymi wiązano 
Do tego dochodzą (powiązane z powyższymi) wyzwania natury ekonomiczno-społeczno-kulturowej, z którymi już dziś nie radzą sobie najbardziej rozwinięte państwa świata: postępująca prekaryzacja rynku pracy ${ }^{31}$, wzrost nierówności społecznych, w tym szczególnie ekonomicznych, sprowadzający się do ogromnych różnic $\mathrm{w}$ dochodach ${ }^{32}$, erozja tradycyjnych struktur rodzinnych, $\mathrm{w}$ tym atomizacja życia społecznego ${ }^{33}$, czy starzenie się społeczeństwa, oznaczające np. zaburzenie tradycyjnej proporcji pomiędzy częścią społeczeństwa produkcyjnego a poprodukcyjnego ${ }^{34}$.

Zasygnalizowane wyżej mechanizmy minimalizacji skutków starych ryzyk socjalnych, czyli ubezpieczenia oraz zaopatrzenie społeczne, prawdopodobnie nie będą w stanie poradzić sobie z nowymi wyzwaniami, gdyż częściowo same stanowią źródło tych zagrożeń. Na przykład niskie świadczenia emerytalne generuje podsystem ubezpieczeń społecznych, tworząc tym samym jedno z nowych ryzyk socjalnych. Nie mówiąc już o tym, iż przypuszczalnie już niebawem będziemy mieli do czynienia $\mathrm{z}$ osobami, które $\mathrm{w}$ wieku poprodukcyjnym $\mathrm{w}$ ogóle nie będą beneficjentami świadczeń z ubezpieczeń społecznych, gdyż przez większość lat pracy były zatrudnione na podstawie umów cywilnoprawnych. Idąc tym tropem, można wręcz pokusić się o stwierdzenie, iż ten podsystem zabezpieczenia społecznego - do tej pory kluczowy w zapewnieniu bezpieczeństwa socjalnego obywateli - będzie stopniowo tracił na znaczeniu.

Tym sposobem dochodzimy do sedna niniejszego tekstu, czyli roli instytucji pomocy społecznej w czasach postindustrialnych. Otóż na wstępie postawiłem hipotezę, iż prawdopodobnie tylko (szeroko rozumiana) pomoc społeczna będzie w stanie poradzić sobie ze wspomnianymi wyżej wyzwaniami. Przypuszczenie to opieram na trzech przesłankach.

Po pierwsze, z powodu funkcji innowacyjnej będącej cechą charakterystyczną tej instytucji. Walor ten - określony przez H. Szurgacza mianem funkcji „pilotującej” lub „pilotażowej” - jest dla wspomnianego autora jed-

nadzieję na skok cywilizacyjny, a które choć gotowe do podjęcia pracy, nie znajdują dla siebie odpowiedniego miejsca, lub jest ono znacznie poniżej ich aspiracji i możliwości”, P.W. Zawadzki, Młodość jako ryzyko, „Problemy Polityki Społecznej. Studia i Dyskusje” 2012, nr 19, s. 52.

31 Zob. G. Standing, Prekariat. Nowa niebezpieczna klasa, Warszawa 2014; K. Chaczko, Prekariusze jako czynnik zmian - ku nowemu etapowi w (europejskiej) polityce społecznej? [w:] Polityka społeczna w zmieniającej się rzeczywistości, K. Chaczko, K.M. Stanek (red.), Katowice 2016, s. 11-28.

32 Zob. T. Piketty, Kapitał w XXI wieku, Warszawa 2015; M. Jarosz, M.W. Kozak, Eksplozja nierówności?, Warszawa 2015.

33 Zob. K. Slany, Alternatywne formy życia małżeńsko-rodzinnego w ponowoczesnym świecie, Kraków 2008; Od obyczaju do mody. Przemiany życia codziennego, J. Zalewska, M. Cobel-Tokarska (red.), Warszawa 2014.

34 Zob. S.A. Nyce, S.J. Schieber, Ekonomiczne konsekwencje starzenia się społeczeństw, Warszawa 2011; Polska w obliczu starzenia się społeczeństwa, A. Karpiński, A. Rajkiewicz (red.), Warszawa 2008. 
ną z „najistotniejszych cech pomocy społecznej, która w dużym stopniu tłumaczy jej żywotność oraz przesądza w określonym stopniu o jej przydatności jako formy zabezpieczenia społecznego nie tylko obecnie, ale również i w przyszłości”35. Tradycja wdrażania nowych elementów w struktury tej instytucji jest bardzo bogata: organizacja kolonii i półkolonii początkowo związana była właśnie z instytucją opieki społecznej, podobnie rzecz się miała $\mathrm{z}$ rodzinami zastępczymi, pomocą alimentacyjną, rentą socjalną czy opieką nad matką i dzieckiem (ryzyko macierzyństwa), wchodzącą obecnie w skład systemu zdrowia oraz ubezpieczeń społecznych ${ }^{36}$. Niektóre rodzaje świadczeń czy rozwiązania organizacyjne, które po raz pierwszy pojawiły się $\mathrm{w}$ tej instytucji, zostały następnie $\mathrm{z}$ sukcesem ulokowane $\mathrm{w}$ innych podsystemach zabezpieczenia społecznego (np. renta socjalna), inne zaś (np. opieka zastępcza) wciąż funkcjonują w ramach systemu pomocy społecznej. Krótko mówiąc, z historyczno-organizacyjnego punktu widzenia doświadczenie otwartości na nowe elementy czy „organizacyjna elastyczność" tej instytucji są niezmiernie istotne w dynamicznie zmieniającej się rzeczywistości naszych czasów ${ }^{37}$. Pojawienie się np. innowacyjnych usług społecznych, adekwatnych do określonych grup społecznych - czy nawet indywidualnych przypadków - wydaje się być koniecznością w zindywidualizowanych czasach nowych ryzyk socjalnych.

Po drugie, z powodu ulokalnienia pomocy społecznej. Żaden podsystem zabezpieczenia społecznego nie jest tak głęboko zakorzeniony w strukturach lokalnych jak omawiana instytucja. Wzajemne wsparcie, opieka czy pomoc społeczna historycznie zakotwiczone były na poziomie lokalnym czy to w przypadku wspólnot religijnych, grup zawodowych czy późniejszej działalności państwa w tym obszarze ${ }^{38}$. W polskich realiach tradycje przedwojenne jak i okres ostatnich 25 lat wyraźnie sytuowały i sytuują pomoc społeczną na poziomie samorządowym ${ }^{39}$. Doświadczenie to ma ogromne znaczenie, gdyż nie ulega wątpliwości, iż „podmioty publiczne działające na szczeblu lokalnym lepiej znają problemy społeczne występujące na danym terenie i mogą - szybciej i lepiej - odpowiedzieć na zapotrzebowanie społeczne w tym zakresie" 40 . Ponadto tzw. trzeci sektor, czyli organizacje pozarządowe działające $\mathrm{w}$ tym obszarze, grupują się na poziomie lokalnym

35 H. Szurgacz, Wstęp do prawa pomocy społecznej..., s. 20.

36 Zob. ibidem, s. 16-18. Por. też P. Grata, Polityka społeczna Drugiej Rzeczpospolitej. Uwarunkowania, instytucje, działania, Rzeszów 2013.

37 Zob. na ten temat Polityka społeczna w zmieniającej się rzeczywistości, K. Chaczko, K.M. Stanek (red.), Katowice 2016.

38 Zob. D. Zalewski, Opieka i pomoc społeczna. Dynamika instytucji, Warszawa 2005.

39 Tradycje ulokalnienia polskiej pomocy społecznej omawiałem m.in. w: K. Chaczko, Czy w systemie opieki społecznej Drugiej Rzeczypospolitej istniały zasiłki pieniężne?, „Praca Socjalna” 2016, nr 2, s. 189-201; K. Chaczko, „Polska w soczewce..., s. 353-372.

40 E. Kulesza, Lokalna polityka społeczna, Warszawa 2013, s. 10. 
- a to właśnie w ich zasobach i potencjalne widzi się przyszłość usług społecznych ${ }^{41}$.

Po trzecie, z powodu wyspecjalizowanej kadry w postaci pracowników socjalnych. Żaden podsystem zabezpieczenia społecznego nie dysponuje tak wysoko i wszechstronnie wykształconą siecią pracowników ${ }^{42}$. Pamiętajmy wszak, iż złożoność problemów społecznych podejmowanych w pracy zawodowej pracowników socjalnych wymusza na tej grupie zawodowej posiadanie wysoko specjalistycznej wiedzy. Mało tego, bez tych umiejętności, czy mówiąc szerzej - kapitału społecznego, nie można nie tylko skutecznie pomagać, ale i rozwijać własnej kariery zawodowej, gdyż dostęp do tego zawodu zawężony jest do osób, które ukończyły kierunek praca socjalna na uczelni wyższej lub kolegium pracowników służb społecznych ${ }^{43}$. Kolejny elementem profesjonalizacji zawodu pracownika socjalnego jest fakt kształcenia ustawicznego czy też specjalistycznego, podobnie jak w zawodach, które status profesjonalizmu osiągnęły już dawno, np. lekarz czy prawnik $^{44}$. Inaczej mówiąc, kapitał społeczny oraz znajomość środowiska lokalnego tej grupy społecznej, zarówno zatrudnionej w instytucjach samorządowych, jak i w organizacjach pozarządowych, powoduje, iż wydaje się, że obecnie jest to jedyna grupa zawodowa gotowa podjąć wyzwania związane z nowymi ryzykami socjalnymi.

\section{Zakończenie}

Dynamika zmian, które następują w społeczeństwach postindustrialnych, powoduje, iż sprawdzone metody minimalizacji ryzyk socjalnych coraz częściej tracą rację bytu, tak jak i niemal cała dotychczasowa polityka

41 Eksperci i badacze związani $\mathrm{z}$ sektorem pozarządowym twierdzą, iż „w realizacji wielu zadań społecznych, w tym usług społecznych, sektor pozarządowy jest niezastąpiony, ze względu na fakt, że szybciej i skuteczniej dociera do odbiorców pomocy, jest bardziej elastyczny, innowacyjny i efektywniejszy finansowo", M. Grewiński, A. Zasada-Chorab, System pomocy społecznej w Polsce. Wyzwania i kierunki, Toruń 2012, s. 35. Por. też T. Kaźmierczak, O potrzebie końca pomocy społecznej, jaka znamy, „Problemy Polityki Społecznej. Studia i Dyskusje” 2014, nr 27, s. 91-105.

42 Grupa zawodowa pracowników socjalnych doczekała się już wielu wartościowych studiów na swój temat. Zob. np. Pracownicy socjalni: pomiędzy instytucją pomocy społecznej a środowiskiem lokalnym, M. Dudkiewicz (red.), Warszawa 2011; Pracownicy socjalni i praca socjalna w Polsce. Między stużba społeczną a urzędem, M. Rymsza (red.), Warszawa 2012; A. Olech, M. Łuczyńska, Pracownicy socjalni w Polsce - portret zbiorowy 2013, Warszawa 2013.

43 Zob. ustawę z dnia 12 marca 2004 r. o pomocy społecznej.

44 A. Zasada-Chorab, Kształcenie pracowników socjalnych - w jakim kierunku zmierzamy [w:] Współczesne tendencje w pomocy społecznej i pracy socjalnej, M. Grewiński, J. Krzyszkowski (red.), Warszawa 2011, s. 85. Mowa tu o specjalizacjach I i II stopnia w zawodzie pracownik socjalny. Zob. rozporządzenie Ministra Pracy i Polityki Społecznej z dnia 17 kwietnia 2012 r. w sprawie specjalizacji w zawodzie pracownik socjalny, Dz. U. poz. 486. 
społeczna, która w dużej mierzy dostosowana była do specyfiki społeczeństwa industrialnego. Oznacza to, iż wypracowane zasady i mechanizmy zapewniania bezpieczeństwa socjalnego stają się coraz bardziej niezdolne do prawidłowej reakcji na pojawiające się problemy społeczne. Wydaje się, iż rację ma G. Esping-Andersen, pisząc w kontekście zmian w polityce społecznej oraz ryzyk socjalnych, iż „Jeśli w przyszłości czekają nas większe nierówności płacowe, które w największym stopniu dotkną młodszych pracowników i młode rodziny, w każdym menu polityki socjalnej na pierwszym miejscu muszą znaleźć się silne gwarancje dochodowe, czy to w postaci subsydiów szkoleniowych lub zatrudnieniowych, kredytu podatkowego od wypracowanego dochodu lub zasiłków rodzinnych"45.

Podejmując ten wątek i biorąc pod uwagę ustalenia poczynione powyżej, można pokusić się o sformułowanie propozycji sposobów minimalizacji skutków nowych ryzyk socjalnych. Otóż wydaje się, iż jednej strony powinny iść działania prowadzące do zwiększania przez państwo dochodu obywateli (np. w przypadku niskich zarobków czy emerytur), a z drugiej strony równolegle musi być położony nacisk na intensywny rozwój sektora usług społecznych, z wyraźnym określeniem priorytetów działań tego obszaru oraz ich indywidualizacji i specjalizacji. Spoglądając z tej perspektywy, trudno zrozumieć, dlaczego coraz częściej termin „państwo bezpieczeństwa socjalnego” (ang. welfare state) zastępuje się kategorią „państwa usług społecznych" (ang. social services state), mającą oddawać koncentrację polityki społecznej na wspomnianych rozwiązaniach ${ }^{46}$.

Obie propozycje - a szczególnie usługi społeczne - łączą się rzecz jasna $\mathrm{z}$ instytucją pomocy społecznej. Zostało powiedziane, iż z powodu funkcji innowacyjnej, zakorzenienia lokalnego oraz wyspecjalizowanej kadry nowa pomoc społeczna wydaje się być najlepiej przygotowana do pełnienia roli instytucji zarządzającej nowymi ryzykami socjalnymi. Napisałem „nowa pomoc społeczna”, gdyż obecne ustawowe ramy funkcjonowania tej instytucji bezwzględnie muszą zostać przekonstruowane ${ }^{47}$. Jeśli pomoc społeczna ma być „uwrażliwiona” na nowe wyzwania społeczne, to instytucja ta musi być organizacyjnie dopasowana do specyfiki płynnej (zmiennej) rzeczywistości. Mam tu na myśli strukturalną zmienność czy proceduralną elastyczność. Otwartość na zmianę to fundament innowacyjności, i to

45 G. Esping-Andersen, Społeczne podstawy gospodarki postindustrialnej, Warszawa 2010, s. 221.

46 M. Grewiński, J. Lizut, Pomoc społeczna jako realizator efektywnych ustug socjalnych..., s. 35.

47 Obowiązującą ustawę o pomocy społecznej z 2004 r. uważam za główną barierę rozwoju tej instytucji. Por. T. Kaźmierczak, O potrzebie końca pomocy społecznej jaka znamy..., s. 91-105. Z kolei propozycję radykalnych zmian w instytucji pomocy społecznej przedstawiłem w: K. Chaczko, (R)ewolucja wyobrażona. O propozycji zmian w systemie pomocy społecznej przy wykorzystaniu programu Rodzina 500 plus, „Praca Socjalna” 2016, nr 3, s. 87-100. 
właśnie dzięki niej „podmioty (...) są w stanie działać lepiej (skuteczniej i efektywniej) (...) i kreować nowe, nieznane dotąd usługi i produkty społeczne" 48 . Krótko mówiąc, efektywność nowej pomocy społecznej powinna być funkcją jej zmienności. Być może należy na nowo zdefiniować idee pomocy społecznej? Być może powinien obowiązywać tylko ramowy przepis normujący tę materię, by zwiększyć moc decyzyjną i kreatywność samorządowych organów prowadzących jednostki organizacyjne pomocy społecznej? Być może potrzebne by były zupełnie nowe instytucje w tym obszarze? Być może należałoby odstępować od kryteriów dochodowych? Być może powinno się większość usług społecznych zlecać trzeciemu sektorowi? Ale na pewno instytucja pomocy społecznej powinna porzucić obowiązujące, sztywne i zbiurokratyzowane ramy proceduralno-organizacyjne, zakorzenione w okresie PRL-u. Tylko wtedy możliwe będzie w pełni wykorzystanie wspomnianego potencjału tej instytucji - waloru innowacyjności, bliskości społeczności lokalnej oraz kapitału społecznego pracowników socjalnych. I tylko wtedy będzie szansa, iż uda się (choć częściowo) zniwelować skutki nowych ryzyk socjalnych.

\section{Bibliografia}

Beck U., Społeczeństwo ryzyka. W drodze do innej nowoczesności, Warszawa 2002.

Błędowski P., Pomoc społeczna [w:] Polityka społeczna, A. Kurzynowski (red.), Warszawa 2006.

Chaczko K., Czy w systemie opieki społecznej Drugiej Rzeczypospolitej istniały zasitki pieniężne?, „Praca Socjalna” 2016, nr 2.

Chaczko K., „Polska w soczewce”. Ewolucja oraz modernizacja systemu opieki i pomocy społecznej w perspektywie instytucjonalnej, „Rocznik Administracji Publicznej" 2016, nr 2.

Chaczko K., Prekariusze jako czynnik zmian - ku nowemu etapowi w (europejskiej) polityce społecznej? [w:] Polityka społeczna w zmieniajacej się rzeczywistości, K. Chaczko, K.M. Stanek (red.), Katowice 2016.

Chaczko K., (R)ewolucja wyobrażona. O propozycji zmian w systemie pomocy społecznej przy wykorzystaniu programu Rodzina 500 plus, „Praca Socjalna” 2016, nr 3.

Chaczko K., Ile jest pomocy w pomocy społecznej? Rzecz o marginalizacji działań usamodzielniających, „Teraźniejszość - Człowiek - Edukacja. Kwartalnik myśli społeczno-pedagogicznej” 2017, nr 1 (77), t. 20.

Esping-Andersen G., Społeczne podstawy gospodarki postindustrialnej, Warszawa 2010.

Grata P., Polityka społeczna Drugiej Rzeczpospolitej. Uwarunkowania, instytucje, działania, Rzeszów 2013.

48 M. Grewiński, A. Karwacki, Wprowadzenie - Innowacyjność jako próba dynamizacji myśli o polityce społecznej [w:] Innowacyjna polityka społeczna, M. Grewiński, A. Karwacki (red.), Warszawa 2015, s. XV. 
Grewiński M., Karwacki A., Wprowadzenie - Innowacyjność jako próba dynamizacji myśli o polityce społecznej [w:] Innowacyjna polityka społeczna, M. Grewiński, A. Karwacki (red.), Warszawa 2015.

Grewiński M., Lizut J., Pomoc społeczna jako realizator efektywnych ustug socjalnych, Toruń 2012.

Grewiński M., Zasada-Chorab A., System pomocy społecznej w Polsce. Wyzwania i kierunki, Toruń 2012.

Innowacyjna polityka społeczna, M. Grewiński, A. Karwacki (red.), Warszawa 2015.

Kaźmierczak T., O potrzebie końca pomocy społecznej jaką znamy, „Problemy Polityki Społecznej. Studia i Dyskusje" 2014, nr 27.

Income Security Recommendation, 1944 (No. 67): http://www.ilo.org/dyn/ normlex/en/f? $\mathrm{p}=$ NORMLEXPUB:12100:0::NO::P12100_INSTRUMENT_ ID:312405.

Jagusiak B., Bezpieczeństwo socjalne współczesnego państwa, Warszawa 2015.

Jarosz M., Kozak M.W., Eksplozja nierówności?, Warszawa 2015.

Kalinowski S., Niewolnicy pomocy - świadczenia społeczne jako czynnik dezaktywujący [w:] Nieobecność społeczna. W poszukiwaniu sensów i znaczeń, Z. Galor, B. Goryńska-Bittner (red.), Poznań 2012.

Krzeczkowski K., Uwagi nad drogami opieki społecznej, Warszawa 1936.

Krzyszkowski J., Kreowanie i wdrażanie innowacji w pomocy społecznej [w:] Innowacyjna polityka społeczna, M. Grewiński, A. Karwacki (red.), Warszawa 2015.

Księżopolski M., Magnuszewska-Otulak G., Gierszewska R., Zabezpieczenie społeczne [w:] Polityka społeczna, A. Rajkiewicz, J. Supińska, M. Księżopolski (red.), Warszawa 1996.

Księżopolski M., Polityka społeczna. Wybrane problemy porównań międzynarodowych, Katowice 1999.

Kulesza E., Lokalna polityka społeczna, Warszawa 2013.

Leksykon polityki społecznej, B. Rysz-Kowalczyk (red.), Warszawa 2001.

Leś E., Zarys historii dobroczynności i filantropii w Polsce, Warszawa 2001.

Nyce S.A., Schieber S.J., Ekonomiczne konsekwencje starzenia się społeczeństw, Warszawa 2011.

Od obyczaju do mody. Przemiany życia codziennego, J. Zalewska, M. Cobel-Tokarska (red.), Warszawa 2014.

Olech A., Łuczyńska M., Pracownicy socjalni w Polsce - portret zbiorowy 2013, Warszawa 2013.

Orłowska-Bednarz M., Bednarz M., Zabezpieczenie społeczne jako forma ochrony warunków życia, „Miscellanea. Studia z Zakresu Nauk Prawnoustrojowych” 2012, nr 2.

Palier B., Ordering change: understanding the „Bismarckian” welfare reformy trajectory [w:] A long goodbye to Bismarck? The politics of welfare reform in Continental Europe, B. Palier (ed.), Amsterdam 2010.

Piketty T., Kapitat w XXI wieku, Warszawa 2015.

Piotrowski J., Zabezpieczenie społeczne - problematyka i metody, Warszawa 1966.

Polityka społeczna w zmieniającej się rzeczywistości, K. Chaczko, K.M. Stanek (red.), Katowice 2016. 
Polska w obliczu starzenia się społeczeństwa, A. Karpiński, A. Rajkiewicz (red.), Warszawa 2008.

Ponikowski B., Problem państwa socjalnego w perspektywie globalizacji [w:] Uwarunkowania współczesnej polityki społecznej, B. Ponikowski, J. Zarzeczny (red.), Wrocław 2002.

Pracownicy socjalni i praca socjalna w Polsce. Między służba społeczna a urzędem, M. Rymsza (red.), Warszawa 2012.

Czepulis-Rutkowska Z., Nowe ryzyka socjalne, „Polityka Społeczna” 2013, nr 11-12.

Pracownicy socjalni: pomiędzy instytucja pomocy społecznej a środowiskiem lokalnym, M. Dudkiewicz (red.), Warszawa 2011.

Radwan-Pragłowski J., Frysztacki K., Społeczne dzieje pomocy człowiekowi: od filantropii greckiej do pracy socjalnej, Warszawa 1996.

Sierpowska I., Istota i zasady udzielania pomocy społecznej [w:] Meritum. Pomoc społeczna. Wsparcie socjalne, I. Sierpowska (red.), Warszawa 2016.

Slany K., Alternatywne formy życia matżeńsko-rodzinnego w ponowoczesnym świecie, Kraków 2008.

Standing G., Prekariat. Nowa niebezpieczna klasa, Warszawa 2014.

Sztompka P., Socjologia. Analiza społeczeństwa, Kraków 2012.

Szumlicz T., Publiczne fundusze socjalne - istota oraz organizacja i funkcjonowanie w Polsce, „Studia z Polityki Publicznej” 2014, nr 1.

Szurgacz H., Wstęp do prawa pomocy społecznej, Wrocław 1992.

Uścińska G., Ryzyko jako przesłanka ochrony w systemie zabezpieczenia społecznego, „Polityka Społeczna” 2013, nr 11-12.

Zalewski D., Opieka i pomoc społeczna. Dynamika instytucji, Warszawa 2005.

Zasada-Chorab A., Kształcenie pracowników socjalnych - w jakim kierunku zmierzamy [w:] Współczesne tendencje w pomocy społecznej i pracy socjalnej, M. Grewiński, J. Krzyszkowski (red.), Warszawa 2011.

Zawadzki P.W., Młodość jako ryzyko, „Problemy Polityki Społecznej. Studia i Dyskusje" 2012, nr 19.

Żarnowska A., Robotnicy Warszawy na przełomie XIX i XX wieku, Warszawa 1985.

\section{Streszczenie}

W artykule omówiono rolę pomocy społecznej w czasach nowych ryzyk socjalnych. W pierwszej kolejności scharakteryzowany został katalog starych ryzyk socjalnych oraz formy minimalizacji skutków tych ryzyk w postaci systemu zabezpieczenia społecznego. Następnie opisano system pomocy społecznej oraz usługi społeczne. Artykuł kończą ustalenia na temat nowych ryzyk socjalnych i roli nowej pomocy społecznej w minimalizacji ich skutków.

Słowa kluczowe: pomoc społeczna, ryzyka socjalne, system zabezpieczenia społecznego, usługi społeczne 


\section{Effectiveness in Variability? Of the Role of Social Welfare in an Era of New Social Risks}

\section{Abstract}

The article discusses the role of social assistance in a time of new social risks. It first characterises old social risks and the social security system and then describes the system of social assistance and social services. The article ends with findings about new social risks and the role of new social welfare in minimising their impact.

Keywords: social welfare, social risks, social security, social assistance 